\title{
Farmer Field School (FFS) and Junior Farmer Field and Life School (JFFLS) as challenges to agricultural extension development and practice in Nigeria
}

\author{
E. N Ajani* and E.A. Onwubuya ${ }^{\star \star}$ \\ Department of Agricultural Extension, \\ Faculty of Agriculture, \\ E-mails: vnglajani@yahoo.com* and lizzybuya@yahoo.com ${ }^{* *}$ \\ Mobile: $07037898918^{\star}$ and $08050338606^{\star \star}$
}

\begin{abstract}
This paper discusses Farmer Field School (FFS) and Junior Farmer Field and Life School (JFFLS) as challenges to agricultural extension development and practice in Nigeria. FFS and JFFLS are participatory extension approaches which emphasize participation of local people and their communities working in groups and building upon the traditional or indigenous knowledge that they have acquired. Discovery learning is emphasized on FFS and JFFLS approaches whereby participants learn by doing as well as discovering new ideas by themselves. The paper suggests the need for promotion of these approaches by national extension policy and donor agencies to ensure sustainability. It notes that these approaches which encourages qualitative rather than often used quantitative researches will reduce unrealistic and crooked formal research data and also challenge other methods of extension delivery for better discovery learning. It concludes that developing an appropriate framework for analysis and evaluation of these approaches will help to more accurately measure their effectiveness and impact on the lives of the participants and the society at large.
\end{abstract}

Key words: Farmer Field School, Junior Farmer Field and Life School, agricultural extension, participatory approaches and discovery learning.

\section{INTRODUCTION}

Agricultural extension can be defined as a conscious provision of information and communication support to rural users of renewable natural resources. It involves offering advice, helping farmers to analyze problems and identify opportunities, sharing information, supporting group formation and facilitating collective action. Extension services are delivered not only by extension agencies but also by farmers, scientists, commercial companies, mass media organizations, among others (Garforth and Lawrence, 1997).

In the last twenty years, many efforts have been made in trying to change research and development in agriculture to better involve farmers, to the extent that it has been widely accepted (Low External Input and Sustainable Agriculture (LEISA, 2006). However, most formal researches related to agriculture in developing countries are still carried out at large research institutions, and the extent to which farmers are involved in setting the agenda, taking part in experiments, monitoring, evaluating or using the results varies a lot, but is generally very limited. LEISA (2006) further stated that the vast range of participatory approaches promoted in the last twenty years have aimed in general at building technical knowledge in order to improve livelihoods ( examples, FFS and JFFLS). The participatory process involves narrowing the gap between research organizations and farmers' realities by ensuring direct farmer involvement at different stages of the research process. 
According to Hellin, Bellon and Badstue (2006), the most effective way for participatory research processes to benefit a greater proportion of farmers is by close coordination and collaboration with organizations that are better placed to link farmers and researchers due to their relatively long-term contact with farmers. These organizations include: extension services, farmer organizations and nongovernmental organizations (NGOs). As these organizations focus on development, they are better placed to ensure that research results reach greater number of farmers and that in the process more farmers are empowered.

A number of agricultural extension approaches have been used in Nigeria. The major differences in their characteristics are based on how the extension services systems are structured and organized, the relationship and linkage mechanisms amongst the extension service actors, particularly farmers, extension agents and researchers, the range of agricultural services contained in the technical package, the types of extension methods that are used and the way the extension services are financed (Ministry of Agriculture, 2008). This paper discusses the concept of Farmer Field School (FFS) and Junior Farmer Field and Life School (JFFLS) and their challenges to agricultural extension development and practice in Nigeria.

\section{Farmer Field School (FFS) Approach}

Farmer Field Schools (FFS) are schools without walls where groups of farmers meet periodically with facilitators during the crop or animal cycle (Davis and Place, 2003). According to FAO (2008), FFS is described as a platform and schools without walls for improving decision-making capacity of farming communities and stimulating local innovation for sustainable agriculture. It is a school without walls that teaches basic agro-ecology and management skills that make farmers experts in their own farms. It is a participatory method of technology development and dissemination whereby farmers are given the opportunity to make a choice in the methods of production through discovery based approach based on adult learning principles and experiential learning (FAO, 2001). It reflects the four elements of experiential learning cycle, namely: concrete experience, observation and reflection, generalization and abstract conceptualization, and active experimentation. These emphasize the importance of learning in practical field settings instead of through didactic modes in classroom settings (Farrington, 2002).

FAO (2008) reported that the specific objectives of FFSs are to:

- empower farmers with knowledge and skills to make them experts in their own fields;

- sharpen the farmers' ability to make critical and informed decisions that render their farming profitable and sustainable;

- sensitize farmers in new ways of thinking and solving problems; and

- help farmers learn how to organize themselves and their communities.

The approach requires a group of $20-30$ farmers to meet regularly on a given farm where they make field observations, relate their observations to the ecosystem and apply their previous experience and any new information to make a crop or livestock management decision with the guidance of a facilitator. The observations are carried out throughout the enterprise cycle (Farrington, 2002). Key non-formal education methods in the Farmer Field School learning include: sharing, case study, role play (dramatized sessions), problem solving exercises, panel 
discussions, group dynamics, small group and large group discussion, brainstorming and simulation game. These key non- formal education methods encourage and contribute to the qualitative nature of this approach thus challenging the usual and often used quantitative methods involved in most formal researches. It also challenges these formal methods by reducing unrealistic crooked data in formal methods as experiential learning is involved through adult learning principles thereby bringing about effectiveness and efficiency in practices. This is achieved as the farmers are empowered with better and more knowledge and skills through their experiences which make them experts in their own fields. The farmers' abilities are also sharpened enabling them to make critical, informed decisions that make their farm production efficient by being profitable and sustainable. The farmers are also sensitised in new ways of thinking and solving problems. The approach challenges farmers to learn how to organize themselves and their communities.

Hein and Muhammad (2007) reported that the Farmer Field School (FFS) approach was developed in the late 1980s in Indonesia. The first FFS networks emerged in Western Kenya in the year 2000 as a result of exchange visits and communication between farmers, facilitators and trainers of different Farmer Field Schools. Similar networks have subsequently emerged elsewhere in Kenya, Uganda and Tanzania. These FFS networks were formed by farmers who had graduated from a FFS. The main reason for their formation was that the graduates wanted to continue the dynamics generated by the FFS process: to build local institutions to ensure the continuation of farmer-led FFS, and benefit from becoming a larger voice in expressing their demands (Arnoud, James, Habakkuk and Godrick, 2007). They further reported that the FFS approach was first introduced in East Africa in 1995 through a project of the Food and Agriculture Organization (FAO) in Western Kenya.

Since then, several projects have been successfully implemented in the region using various different entry points, including issues such as integrated production and pest management, land and water management, self sustainability for refugee communities, integrated crop management of sweet potato, promotion of farmer innovations, livestock and control of banana bacterial wilt. To date, the FFS networks in East Africa support about 2000 FFSs with close to 50,000 direct beneficiaries. The main reason for the success of FFS in the region has been the involvement of farmers in identifying their problems, in selecting, testing and evaluating possible solutions. This paper is advocating that this approach should challenge (be used as a challenge) in the Nigerian extension service delivery and system to bring about such networks to generate dynamics and processes to build up local institutions and benefits (or that will benefit farmers) sufficiently.

The approach is currently one of the fore-front extension-related activities sponsored by FAO, and the principles and methodology of the approach are being replicated by other technical services such as irrigation and water use and forestry. Irrigation and Water Use technical unit has already successfully piloted a FFS project in Zambia (FAO, 2008). FAO's Forestry Policy and Institutions branch have also adopted the FFS approach, but have changed the name to suit its community forestry development purposes: Farmers' Forest Management Schools (FFMS). The Farmer Field School approach is relatively new to West Africa, and there are few examples of its application to tree crops and perennial crops. Sustainable Tree Crop Programme (STCP) has pioneered FFS on cocoa integrated crop and pest management in Cote d'Ivoire, Ghana, Nigeria, and Cameroun since 2003. Although it is based on the experience built with cocoa FFSs, many of the principles and 
recommendations can be applied to FFSs on other tree crops (Soniia, 2006). FAO (2008) also reported that other African countries implementing this approach are Zimbabwe, Malawi, Ethiopia, Gambia, Egypt, Lesotho, Swaziland and Mozambique. Hence the approach is being advocated for Nigeria as a challenge to our usual extension service delivery methods.

According to Agro Care (2009), feedback from farmers and operators of the Farmer Field School (FFS) from Edo state, Nigeria have shown that this agricultural extension approach is capable of improving farm yields tremendously, particularly in the cocoa sub-sector where it is presently being put into use and in which many more farmers and states are adopting it. The programme, jointly funded by the federal government, cocoa producing states and the International Institute for Tropical Agriculture (IITA)'s Sustainable Tree Crop Programme (STCP), is a school without border and is held fortnightly in the field in cocoa producing communities where FFS is located. FFS was adopted by the Sustainable Cocoa Development Committee (SCDC) in 2005 as an improved methodology for training cocoa farmers in Nigeria. The approach can be tried and used to challenge other areas of agriculture such as yam, rice and cassava producing areas as in the case of these cocoa producing areas. The overall objective of the project was to strengthen the capacity of the extension services of participating states to use the FFS extension approach to develop, implement and manage cocoa integrated crops and pests management.

Following the adoption, the Sustainable Tree Crop Programme (STCP) of the IITA was commissioned to develop and implement the FFS capacity building project for the cocoa producing states. A total of 14 master trainers, 27 supervisors and 156 facilitators have been trained. Of these numbers, 12 master trainers, 24 supervisors and 136 facilitators from eight states have had at least a year experience in running FFS in their states. Besides, efforts are being made to constitute the Edo State Cocoa Development Committee, which would immediately be followed by the inauguration of the Local Governments Cocoa Development Committees, all aimed at enhancing the nation's cocoa production capacity and repositioning the country in the league of cocoa producing nations (Agro Care, 2009). Other states of the federation should attempt to take up this challenge and replicate it for agricultural production and practices that suits their region or introduce other.

Olukayode (2009) reported that Edo state presently has 22 Farmer Field Schools, second to Osun state which has 30 . The first cycle of the state's Farmer Field School programme commenced in September 2007 and ended in October 2008 , with the graduation of 500 cocoa farmers. The second cycle was officially flagged-off by Edo state deputy governor on Monday, $18^{\text {th }}$ May, 2009 at Aihuobabekun/Obarenren Farmer Field School in Ovia North-East local government area of the state, with over 500 cocoa-farmer participants attending. FFS as an informal institution is based on the assumption that farming communities have a vast body of knowledge, skills and experience on which they can build their future. The local farmer's knowledge and insights are based on their vast experience, rooted in their own local context (Raklin and Ajay, 2007). In this case, existing knowledge, values, cultures and practices are the key knowledge resources.

According to LEISA (2001), in field schools, farmers learn to conduct experiments independently, create learning materials on their own, and manage field laboratory and plan for special sessions such as Integrated Pest Management (IPM) field days or IPM popular theatre. Farmers do not master a specific set of contents 
or messages, rather they master a process of learning that can be applied continuously to a dynamic situation. Field school intentionally included processes and methods that would provide such interaction. Participants work together in small groups to collect data from the field, generate analysis through discussion, present results, conduct experiments and make group decisions for field management. For many farmers unaccustomed to even speak in front of groups, this confidence building and process mastery is the most important outcome of their field school experience (Russ, 2007). This approach will challenge the collection of fake data common in quantitative research as small groups are involved in qualitative field data collection for analysis, discussions and effective group decisions.

The operation of the extension delivery approach is that developmental organizations partner with extension personnel to identify or form farmer groups based on particular topics. For instance, there are groups based on passion fruit, poultry, beekeeping and vegetable production. Farmer Field Schools hold field days for other FFS groups and neighboring farmers. This is a chance for each participant to teach others what they have learnt. At the end of the FFS cycle, certain farmers are chosen by the group to be farmer facilitators. They can then lead their own Farmer Field School the next season (Davis and Place, 2003). Madukwe (2006) noted that the FFS have transformed farmers from recipients of information to generators and manipulators of local data.

One important issue in FFS is that of sustainability without outside funding. It is a participatory approach, which facilitates farmer's demand for knowledge and offers opportunity for the end users to choose, test and adapt technologies according to their needs. Through participation in FFS, farmers develop skills that allow them to continually analyse their own situation and adapt to changing circumstances (Madukwe, 2006).

\section{Junior Farmer Field and Life School (JFFLS) Approach}

HIV and AIDS have a tremendous impact on rural African societies: families and social networks of solidarity are disrupted, children are orphaned, the rural livelihoods and the mechanisms of knowledge transmission are grievously affected (Djeddah, 2005). She further reported that the growing number of orphans is of direct concern to all sectors. Rural children orphaned by AIDS are more likely than other orphans to be at risk from malnutrition, disease, abuse and sexual exploitation. Often, orphaned children are growing up without the necessary knowledge and skills for their future livelihoods. From the farm-household perspective, food security is affected: both the quantity and quality of the food diminishes and orphans can often go hungry or are malnourished. From an agricultural perspective, these young boys and girls need to have the necessary agricultural and livelihood skills, the education and the food required to grow into healthy adults and become agents of their own change. The JFFLS objective is to improve their livelihoods and provide them opportunities for long-term food security, while minimising the vulnerability to destitution and extreme coping strategies (LEISA, 2007).

Junior Farmer Field and Life Schools (JFFLSs) were developed by FAO, together with the World Food Programme (WFP), other UN agencies, national governments, NGOs and local institutions, as a way to counter the impact of HIV and AIDS on orphans and vulnerable children, to reduce their vulnerability and to improve their livelihoods and long-term food security. FAO has established JFFLSs in several African countries since 2004, with the objective of mitigating the impact of 
AIDS epidemics on the rural populations and specifically empowering orphans, vulnerable children and youths by improving their livelihoods and their agricultural and life skills (FAO, 2007).

Djeddah, Mavanga and Hendrickx (2005), reported that the JFFLSs are an adaptation of two successful participatory learning methodologies to the needs of rural youths: During an agricultural season, a group of 30 children/youths (boys and girls between 12 and 17 years) follow the life cycle of crops and make links and inferences regarding their own lives and problems. They meet once, twice or thrice a week in the field, and learn by doing and exploring. An inter-disciplinary team of facilitators accompanies the children to the field: a school teacher, an agriculturist / extension worker and a social animator, proficient in drama, dance and creative activities. Community volunteers always work in close collaboration with the facilitators. The curriculum of the JFFLS is built on four main pillars, namely:

- school site and the field activities where children learn by doing;

- special agricultural topics;

- life skills and

- cultural activities (theatre, dance, singing etc).

The learning activities in the school site follow the local agricultural cycle, depending on the choices of the children and people of the community who own the project. The activities range from laying out the site, preparing the land, seeding or planting, weeding, thinning, constructing suitable storage units, storing harvests, making compost, managing livestock, establishing a nursery and irrigating vegetables. The JFFLS curriculum integrates and links the agricultural learning with life skills according to monthly themes, with a holistic perspective, which is its trademark and peculiarity. Art, theatre, song and traditional dance play a central role in encouraging self-expression and integration with peers; they also help to build trust, explore risks, solve problems and develop more gender-equal attitudes (Dimitra Newsletter, 2007).

The JFFLSs were developed as a pilot initiative in Mozambique in 2003. Since then, they are refined, scaled up and enthusiastically adopted by different stakeholders in nine African countries, namely: Kenya, Malawi, Namibia, Sudan, Swaziland, Tanzania, Uganda, Zambia and Zimbabwe. The JFFLSs are now embedded in the formal education system in most cases, providing new inputs to this sector in terms of participatory learning and good agricultural and life practices. When possible, the JFFLSs are also co-coordinated with the adult FFS network (Djeddah, 2005).This paper advocates that Nigeria joins these African countries in this regard using it as a challenge to stimulate our own version that could be called youth for Agriculture(YFA) Programme which can be embedded in our school programme for youths in school to improve agricultural production and practices in Nigeria. This will also enable the youths to be self reliant and improve their livelihood thus reducing their vulnerability.

This approach according to Djeddah ( 2005) has been expanded to the Kakuma refugee camp in Kenya since 2006, with a particular focus on orphans and vulnerable children resulting from civil violence and displacement, with support provided by the United Nations System-wide Work Programme on scaling-up HIV/AIDS services for populations of humanitarian concern. Spore (2008) also reported that in Mozambique, the education and training on Junior Farmer Field and Life Schools (JFFLS) programme has trained 7,000 AIDS orphans in an effort to stop them from leaving their communities. These young people have not just acquired 
farming skills and knowledge; they have also developed the capacity to understand their problems and ensure that their rights are respected.

Food and Agricultural Organization of the United Nations (FAO) identified the Junior Farmer Field and Life School (JFFLS) concept as a useful way to assist rural youth in HIV/AIDS programmes. The JFFLS programme provided technical, business and life skills, while at the same time providing some constructive activities to get junior farmers started in income generating enterprises to help support their families and themselves into the future (LEISA, 2007). This can be replicated in Nigeria for our myriads/ vast youths especially unemployed school leavers so as to contribute to national development. Example, the Nigerian government through extension system can consolidate this approach (JFFLS) by empowering the youths through acquisition of agricultural skills that will make them experts in their own fields. Viable strategies of sustainability can be devised by developing alliances with government, Non- Governmental Organizations and extension agencies to scale up the JFFLS. Such strategies should/ may include developing appropriate framework for evaluating the approach. There should be proper/ efficient maintenance of its technical qualities and core non- negotiable elements such as unique synergy between agricultural skills, life skills and the participatory field experience by the extension service.

JFFLS have been labelled as one of the FAO's "Best practices". The key challenges are:

- consolidation of the approach;

- devising viable strategies of sustainability by developing alliances with governments, NGOs and United Nations partners to scale-up the JFFLS and

- maintaining its technical quality and core non-negotiable elements, namely, unique synergy between agricultural skills, life-skills and the participatory field experience (FAO, 2005).

\section{Conclusion and Recommendations}

The approaches challenges agricultural extension development and practice in Nigeria by encouraging qualitative extension delivery, practice and research through encouraging realistic methods in them. This paper advocates that the approaches be used to challenge our extension delivery system to bring about networks to generate dynamics and processes which could be used to spring up local institutions and benefits for our teeming unemployed Nigerians, young and old.

Effective participation of farmers in Farmer Field Schools (FFS) will enhance development of appropriate skills in farming thus necessitating formation of groups that facilitate effective dissemination of agricultural information within a social system. Vulnerable children and orphans who participate in Junior Farmer Field and Life Schools acquire agricultural skills that empower them and also improve their livelihoods. In order to support sustainable agriculture, extension approaches should use extension resources to support the development of independent client organizations, work increasingly to influence and facilitate planning decisions and action at group and community levels; and incorporate bottom-up and interactive approaches for extension planning and technology development. The national extension policy and donor agencies should promote changes in extension approaches, which will enhance sustainability rather than merely increase efficiency of contact with clients and the relevance of top-down technology development and information delivery. 


\section{References}

Agro Care (2009). Farmers' Field School: An Agricultural Extension Model. Agro Care Newsletter, 1.

Arnoud, R. B, James, R.O, Habakkuk, K and Godrick S.K (2007). Building Farmer Field Schools networks in East Africa. LEISA Magazine, vol.23 (1): 18.

Davis, K and Place, N (2003).Current Concepts and Approaches in Agricultural Extension in Kenya. Proceedings of the $19^{\text {th }}$ Annual Conference of AIAEE. Raleigh, North Carolina, USA,745-756.

Dimitra Newsletter (2007). Junior Farmer Field and Life Schools: A response to counter the impact of HIV and AIDS on orphans and vulnerable children in Southern and Eastern Africa. No. 13 (15).

Djeddah, C (2005). Junior Farmer Field and Life School, empowering orphans and vulnerable children living in a world with HIV/ AIDS: Concept paper. FAO/WFP

Djeddah, C, Mavanga, R and Hendrickx, L (2005).Junior Farmer Field and Life Schools: Experience from Mozambique. In Gillespie, S (eds). AIDS, poverty and hunger: Challenges and responses, IFPRI.

Farrington, J (2002). Recent and Future Challenges in Agricultural Extension, Overseas Development Institute (ODI), London, LEISA Magazine, vol. 4 (2): 8.

Food and Agriculture Organization (2001). Farmer innovation and new technology options for food production, income generation and combating desertification $(99 / 2000)$.

Progress report- 2001. Nairobi, Kenya. Food and Agriculture Organization of the United Nations.

Food and Agriculture Organization (2005). Harvesting for life, movie, director: Boudicca Downes.

Food and Agricultural Organization (2007). Getting started! Running a Junior

Farmer Field and Life School, FAO/WFP. www.fao.org.

Food and Agriculture Organization (2008). FAO's current programmes for Agricultural and Rural Extension Worldwide. FAO corporate document Repository, 1.

Garforth, C and Lawrence, A (1997). Supporting sustainable agriculture through extension in Asia. Natural Resource Perspectives, No 21. London: Overseas Development Institute (ODI), London

Hein, B and Muhammad, A.I (2007). Changing the strategies of Farmer Field Schools in Bangladesh. LEISA Magazine, vol. 23 (4): 21.

Hellin, J, Bellon, $M$ and Badstue, L (2006). Bridging the gaps between researchers' and Farmers' realities. Impact, Targeting and Assessment Unit, International Maize and

Wheat Improvement Center (CIMMYT), China. LEISA Magazine, vol. 22 (3): 6.

Low External Input and Sustainable Agriculture (2001). Lessons in scaling up. LEISA Magazine, vol. 1(3): 18.

Low External Input and Sustainable Agriculture (2006). Building knowledge, vol. 22 (3): $4-8$

Low External Input and Sustainable Agriculture (2007). Junior Farmer Field Schools in Zimbabwe. LEISA Magazine,vol.23 (3): 9. 
Madukwe, M.C ( 2006 ). Delivery of Agricultural Extension Services to Farmers in Developing Countries. CTA publications, Wageningen, Netherlands, 1-3.

Ministry of Agriculture (2008). Agricultural approaches to Agricultural Research and Extension. Wageningen, Netherlands, 1-2.

Olukayode, O (2009). Farmers' Field School: An Agric Extension Model. Agro Care Newsletter, 1

Rakhi, S and Ajay, S (2007). Farmer Field School: Farmer centric agriculture extension approaches. LEISA India Magazine, vol. 9 (1): 28.

Russ, D (2007). From Farmers' Field Schools to community IPM. LEISA Magazine, vol. 17 (3): 18.

Soniia, D (2006). A guide for conducting Farmer Field Schools on cocoa integrated pest management. International Institute of Tropical Agriculture (IITA), Sustainable Tree Crops Programme, Accra, Ghana. http:www.treecrops.org.

Spore Magazine (2008). Agricultural training: An imperative need. CTA publications, Netherlands, No. 136, 11. 